\title{
ANALISIS KRITIS EKSISTENSI NILAI PATRIOTISME DALAM PENDIDIKAN KEWARGANEGARAAN
}

\author{
R. Samidi ${ }^{\bowtie}$, Wahyu Jati Kusuma \\ Universitas Pancasakti Tegal, Indonesia
}

\begin{tabular}{l}
\hline Info Artikel \\
\hline SejarahArtikel: \\
Disubmit Juni \\
Direvisi Juni \\
Diterima Juni \\
\hline Keywords: \\
critical analysis, \\
patriotism, Citizenship \\
Education \\
\hline
\end{tabular}

\section{Info Artikel}

\begin{abstract}
Abstrak
Tujuan penulisan ini ialah mengeksplorasi eksistensi nilai patriotisme melalui Pendidikan Kewarganegaraan di beberapa negara dengan mengacu pada teori sosial Durkheim dan politik Rousseau. Tulisan ini mendeskripsikan tentang konsep dasar patriotisme, jenis-jenis patriotisme, kritik patriotisme, patriotisme di dunia pendidikan, dan pentingnya Pendidikan Kewarganegaraan sebagai bentuk solusi dalam menanamkan nilai-nilai patriotisme. Jenis penelitian ini menggunakan metode studi kepustakaan dengan mengumpulkan data dari hasil pengkajian dari buku primer dan jurnal-jurnal ilmiah. Hasil dari pengkajian beberapa literatur menunjukkan bahwa di beberapa negara, Pendidikan Kewarganegaraan dijadikan sebagai alat sosialisasi dan mempunyai peranan penting dalam menanamkan nilai-nilai patriotisme dengan tujuan terbentuknya warga negara yang memiliki karakter peduli serta cinta terhadap bangsa dan negara.

Abstract

The purpose of this paper is to explore the existence of the value of patriotism through Citizenship Education in several countries with reference to Durkheim's social theory and Rousseau's politics. This paper describes the basic concepts of patriotism, types of patriotism, criticism of patriotism, patriotism in the world of education, and the importance of Citizenship Education as a form of solution in instilling patriotism values. This type of research uses the method of library study by collecting data from assessment results from primary books and scientific journals. The results of the review of several literature shows that in some countries, Citizenship Education is used as a socialization tool and has an important role in instilling patriotism values with the aim of forming citizens who have the character of caring and love for the nation and state.
\end{abstract}




\section{PENDAHULUAN}

Sejalan dengan perkembangan IPTEK, susahnya filterisasi budaya asing membuat generasi muda terseret arus perkembangan budaya luar yang mengakibatkan mulai lunturnya jiwa nasionalme dan patriotisme pada generasi muda bangsa. Di era globalisasi saat ini menjadi sebuah perdebatan tentang perlu atau tidaknya dalam mengajarkan atau mempelajari patriotisme di sekolah. Berkaca dari beberapa sekolah di negara maju seperti Amerika Serikat, Israel, dan Inggris sudah menanamkan nilai-nilai patriotisme mulai dari Sekolah Dasar. Hasil penelitian yang dikemukakan oleh Macedo (2011: 217) bahwa sebagian besar negara di dunia menanamkan nilai-nilai patriotisme dalam isi kurikulum di sekolah dengan tujuan memperkuat eksistensi sebuah negara. Namun yang menjadi pertanyaan adalah apakah sosialisasi patriotisme di sekolah benar-benar mengajarkan nilai patriotisme yang sejati?

Paham patriotisme merupakan sebuah kejiwaan yang mempertaruhkan kesetiaan secara total diabdikan langsung kepada negara atas nama seluruh bangsa. Budiyanto (2007: 23) mengemukakan terdapat 7 (tujuh) komponen yang dapat meleharikan generasi muda yang berkualitas, salah satunya yaitu menunjukkaan kerelaan berkorban untuk kepentingan bangsa dan negara. Oleh karenanya untuk membentuk jiwa patriotik sejati,maka perlu diajarkan dan ditanamkan sejak dini melalui pendidikan sekolah. Sekolah merupakan titik awal dalam mengajarkankan nilai-nilai patriotisme, kemudian diaplikasikan dalam kehidupan bermasyarakat, karena pendidikan patriotisme merupakan bagian dari pendidikan sepanjang hayat guna tetap menjaga kedaulatan negara dari ancaman negara lain baik itu dari segi ekonomi, budaya, dan militer. Hal ini didukung dari hasil penelitian Encep (2017: 69-82) yang menyatakan sekolah dan universitas menjadi konsern dan menjadi wadah dalam menumbuhkan bibit-bibit nilai nasionalisme dan patriotisme walaupun dalam implementasinya belum sepenuhnya sempurna.
Adapun wadah dalam proses penanaman patriotisme di lingkungan sekolah adalah melalui Pendidikan Kewarganegaraan. Pendididikan Kewarganegaraan merupakan sebagai bentuk usaha dalam mempersiapkan peserta didik untuk mengembangkan kecintaan, kesetiaan untuk berkorban membela bangsa dan tanah airnnya. Untuk menciptakan warga negara yang tangguh, maka sangat perlu diajarkan dasar-dasar nasionalisme dan patriotisme di sekolah sebagaimana di beberapa negara seperti, Amerika dan Inggris, dan Indonesia. John Patrick (1999) sebagai salah satu pemerhati Pendidikan Kewarganegaraan, dalam bukunya membagi konsep-konsep dasar Pendidikan Kewarganegaraan yang termuat di sekolah. Salah satunya yaitu civic identity dengan lebih menakankan pada pengenalan jati diri dari setiap warga negara dengan menanamkan semangat nasionalisme dan patriotisme. Sebagaimana yang diungkapkan oleh Antony Smith (1991: 14) bahwa pada dasarnya civic identity (identitas warga negara) akan melahirkan ideologi nasionalisme dan patriotisme disebabkan persamaan sejarah, budaya, dan wilayah. Oleh karenanya menurut Baranson (1999) Pendidikan Kewarganegaraan memiliki perananan penting dalam menciptakan warga negara yang memiliki pengetahuan kewarganegaraan, keterampilan kewarganegaraan, dan sikap kewarganegaraan.

\section{METODE}

Jenis penelitian yang digunakan dalam tulisan artikel ini yakni dengan metode studi kepustakaan (Nazir, 2003). Metode pengumpulan data yang digunakan dengan menelaah sumber-sumber kepustakaan yang berasal dari buku primer dan jurnal-jurnal ilmiah terkait eksistensi nilai patriotisme dalam Pendidikan Kewarganegaraan. Kemudian data yang diperoleh dianalisis secara induktif sesuai dengan permasalahan terkait dengan eksistensi nilai patriotisme dalam Pendidikan Kewarganegaraan.

\section{PEMBAHASAN}

\section{Konsep Dasar Patriotisme}


Konsep patriotisme sebagaimana yang diungkapkan oleh Archard (199: 159) bahwa patriotisme merupakan cinta terhadap negara atau bangsa dengan bertindak secara tertentu dengan cara mengorbankan diri atas nama negara atau bangsa. Sejalan dengan apa yang dikemukan oleh Merry (2009: 379) pengertian patriotisme lebih mengarah pada keterkaitan atau simpati (afinitas) yang dimiliki oleh seseorang terhadap tanah air mereka sehingga menimbulkan keterikatan dan kebanggaan secara psikologis yang mendalam. Lebih khusus lagi Plumbo (2009: 322) mendefinisikan patriotisme sebagai sebuah identitas, merupakan kekuatan sosial yang memiliki fungsi menjaga individu terpisah-pisah dengan membentuk sebuah kelompok atau komunitas yang lebih jauh yang disebut dengan negara. Jika kita melihat ketiga pendapat diatas bahwa nasionalisme dan patriotisme tidaklah sama dari segi konsep, jika nasionalisme lebih kepada bagaimana warganegara menciptakan sebuah identitas yang sama untuk menyokong sebuah kedaulatan negara. Sementara patriotisme lebih kepada bagaimana penyerahan baik itu jiwa dan raga serta harta dalam memperthankan kedaulatan dari sebuah negara. Seseorang yang nasionalis juga menjadi patriot, kesetiaan terhadap negara dengan bentuk loyalitas merupakan inti dari ajaran nasionalisme (Archard, 1999: 159).

Uapaya sistematis untuk menganalisis patriotisme sebagai sebuah identitas dan kekuatan motivasi berasal teori politik dari Rousseau. Bagi Rousseau, patriotisme merupakan sebuah penopang antara sukarelawan yang dalam hal ini warga negara terhadap negaranya dengan memiliki gagasangagasan kebajikan yang diwarisi dari negaranaya (Palumbo, 2009: 322). Maksud dari teori ini, Rousseau memiliki pandangan bahwa terdapat sebuah ikatan yang mengikat (kontrak sosial) warga negara secara bersama-sama dimana negara memiliki gagasan tentang konsep kebajikan untuk warga yang memiliki sifat sukarela dalam kesetiaan terhadap negara. Seorang dikatan patriot berkomitmen dan berpikir bahwa negaranya menjamin pengabdiannya, memiliki perasaan untuk mencari kesamaaan antara cita-cita bangsa dan negaranya tanpa memiliki pandangan mengenai status politik negaranya. Sedangkan Emeil Durkheim menyoroti kekuatan patriotisme dalam membangun solidaritas warga, dengan menggunakan pendekatan teori klasik sosial. Durkheim memiliki sebuah pandangan bahwa patriotisme merupakan sebuah elemen penting dalam mengembangkan solidaritas yang bersifat alami yang memungkinkan warga negara untuk melestarikan kohesi internal dan identitas kelompok sehingga tidak akan menimbilkan runtuhnya tatanan sosial yang merupakan warna dari sebuah negara (Palumbo: 323). Sehingga Simon Keller mengibaratkan sikap patriot seperti apa yang diutarakan "anda tidak hanya memutuskan untuk mencintai seseorang, atau berhenti mencintai seseorang dengan cara yang sama, seorang patriot memiliki hasrat untuk negaranya bahwa dia tidak hanya memilih untuk memiliki, dan tidak begitu saja memilih untuk memberantasnya" ( Herbert, 2012: xiv). Maksud dari pernyataan Simon bahwa sikap patriotisme yang muncul pada diri seseorang dikarenakan ada rasa simpati dan empati terhadap negara di mana dia lahir sehingga terdorong untuk cinta terhadap negara di mana seseorang itu berada.

Pada dasarnya,nasionalisme dan patriotisme memiliki kepercayaan yang faktual dimana terkandung eksistensi bahwa negara memiliki kepentingan moral dalam membangun bangsa agar setiap elemen bangsa bekerja dan berjuang keras mencapai jati diri dan kepercayaan sebagai sebuah bangsa. Bangsa yang nasionalis pasti menjadi seorang yang patriot dikarenakan kesetiaan terhadap negara adalah salah satu bentuk loyalitas yang harus dipenuhi.

\section{Jenis-Jenis Patriotisme}

Menurut Michalinos Zembylas (2013: 1146-1147) membagi jenis patriotisme menjadi empat. Pertama patriotisme republik neoklasik, fokus gagasannya tentang konsep kebebasan politik dan kebajikan masyarakat. Dalam hal ini konsep nasionalisme dibedakan dari patriotisme dan dipahami sebagai sebuah cinta kebebasan 
politik serta penguatan kesadaran kewarganegaraan dari pada cinta bahasa atau etnisitas. Jenis patriotisme republik neoklasik menentang otoritarianisme, tirani, despotisme dan penindasan. Kedua yaitu patriotisme komunitarian moderat, dimana patriotisme dipahami dimana hegemoni pemerintah lebih kuat. Patriotisme ini mencoba menjembatani republikanisme dan komunitarianisme. Jadi patriotisme ini selalu didefinisikan secara politis. Ketiga, patriotisme liberal moderat dimana melihat liberal sebagai sebuah batasan moral secara universal yang mengarah pada tujuan patriotik. Walaupun liberalisme menjadi sebuah perdebatan terlalu kental hegemoni liberalisme tidak dianggap sebagai sesuatu hal yang baik, maka disini patriotisme harus menjadi penengah dalam hal menahan solidaritas dan loyalitas keanggotaan. Keempat yaitu patriotisme moderat, dimana patriotisme ini menyiratkan kesetiaan konstitusi sebagai dasar patriotisme. Loyalitas patriot dengan mengususng nilai-nilai demokrasi yang diwujudkan oleh konstitusi.

\section{Sedangkan Archard (1999: 158)} didalam tulisannya membagi patriotisme menjadi dua, yaitu patriotisme sejati atau patriotisme kritis dan patriotisme palsu. Patriotisme sejati atau kritis yaitu patriotisme yang negara tidak memanfaatkan kesetian warga negara terhadap hal-hal yang bisa merugikan negara sendiri dan merugikan negara orang lain atau sebaliknya warga negara tidak merugikan negara sendiri demi kepentingan negara lain. Merry sangat mendukung patriotisme kritis, yang dikembangkan melalui cara-cara yang tidak koersif, yang mendorong kemampuan untuk mengungkapkan perbedaan pendapat dan moral warga negara dalam menggapai cita-cita nasional dikompromikan (Merry, 2009: 380)

Patriot kritis mengacu pada realisasi cita-cita nasional menjangkau seluruh warga negara. Kesejahteraan warganegara sampai di luar perbatasan nasional adalah bagian dari peran warga patriotik kritis itu sendiri (Haynes, 2009: xv). Sementara yang dikatakan patriotisme palsu yaitu warga negara yang memiliki loyalitas terhadap negaranya tetapi lebih bersifat merusak karena adanya kepentingan yang membawa dampak buruk kepada bangsa atau negara orang lain. Contoh Patriotisme palsu seperti yang digambarkan Archard yakni ketika tentara angkatan laut Jerman dalam perang di Belgia dimana tentara angkatan bersenjata Jerman menenggelamkan kapal Lusititania, yang dimana isinya warga sipil, diantaranya ada anak-anak, wanita dan warga sipil lainnya. (Archard, 1999: 158). Jadi disini perlu digaris bawahi bahwa perlunya memberikan pemahaman kepada anak-anak dan warga negara bahwa patriotisme palsu memiliki sifat materialisme (menghitung sebuah bangsa dengan kekuatan) dan militerisme (berusaha memajukan negara dengan sebuah kekerasan)

\section{Kritik Patriotisme}

Sebuah komunitas atau negara dalam sekala besar menganggap konsep sejarah dari sudut pandang patriotisme dengan menceritakan kisah-kisah hero atau sikap kepahlawanan dirancang menanamkan solidaritas dan pengabdian. Ada sebuah argumen yang sangat kuat mendukung pandangan bahwa patriotisme tidak akan pernah dibenarkan. Seperti yang dikatan Kateb (2006: 7) bahwa patriot penuh dengan bahaya moral dan tempat pelindung bagi orang-orang tidak bertanggung jawab, dengan manuver politik yang terorganisir yang mengatas namakan kesetiaan kepada negara. Pernyataan Kateb didukung juga oleh Callan (2009: 252), di dalam tulisannya menyatakan anti patriotisme diadopsi sebagai respon terhadap penindasan atas kejahatan berat lainnya yang dilakukan atas nama negara yang dicintai. Begitu juga Simon Keller mengungkapkan bahwa patriotisme adalah sebuah itikad buruk dan bentuk loyalitas tidak didasarkan pada penilaian yang netral terhadap karakteristik berharga dari obyek (warga negara) patriotik itu sendiri (Porath, 2007: 42). Karakteristik berharga disini menurut Keller mencakup moralitas tinggi, komitmen nilai mulia, yang dinilai netral dalam sebuah negara. Sehingga ini menjadi sebuah kekhawatiran Martha Nassbaum bahwa 
patriotisme bertentangan dengan perjuangan untuk keadilan (Ben Porath, 2007: 43).

Meliahat dari beberapa pendapat para kritikus patriotime, mereka berpandangan bahwa patriotisme sangat berbahaya dan merupakan kejahatan yang sangat mengerikan jika tersisipi sebuah kepentingan politik yang bersifat destruktif dan patriotisme dijadikan alat oleh negara sebagai stimulus kepada warganegara untuk taat dan patuh. Akibat dari itu akan terciptanya sebuah hegemoni kekuasaan sehingga terjadi. Sebagai contoh banyaknya peperangan yang mengakibatkan kerusakan, munculnya rasisme karena menganggap negara atau bangsa mereka paling kuat dan dominan mengakibatkan lahirnya nasionalis ekstrimis seperti kasus rasisme Nazi yang anti-semitisme, kaum kulit hitam (apartheid) di afrika selatan yang dijual dan dijadikan budak di negara Amerika. Terjadi juga di negara Jepang selama perang dunia II, kelompok warganegara patriotik lebih unggul, yang mengakibatkan semakin memperburuknya situasi perang, dengan alasan semangat nasionalisme sebagai alat untuk membenarkan perang bahkan mereka yang sudah berkomitmen untuk perdamaian harus smendukung usaha perang (Kanako, 2009: 444). Tetapi Ben Porath (2007: 44) berusaha untuk mengambil jalan tengah dengan mengusung demokrasi sebegai prinsip pemerintahan yang demokratis yang dijadikan alat untuk membatasi konsep patriotisme. Jadi penggambaran patriotisme menurut Ben Porath adalah rasa berafiliasi bangsa terhadap negaranya dengan cara mendukung beberapa tujuan pemerintahan yang demokratis seperti toleransi, perhatian terhadap kebijakan public dan penghormatan terhadap hak.

\section{Patriotisme dalam Dunia Pendidikan}

Konsep pendidikan pada dasarnya merupakan aspek yang penting sekali dalam kemajuan dan kondisi suatu bangsa dan negara (Novitasari, 2013: 39). Haynes mengambil sebuah pandangan bahwa mendidik adalah sebuah bentuk kesadaran kewarganegaraan dan tanggung jawab dalam menegakkan sebuah keadilan (Haynes, 2009: xvii). Mengajarkan patriotisme merupakan sebuah tuntutan karena tujuan utamanya yaitu supaya warga negara merasa memiliki identitas dan mencintai negara mereka adalah sesuatu alasan yang dapat dipertahankan secara kritis (Archard, 1999: 166). Dengan memperluas batasan-batasannya, memperkaya bebrbagai perspektif yang mendukung masyarakat untuk bersatu dalam rangka menyiapkan diri dari bahaya konflik dengan tujuan jangka panjang untuk melahirkan sebuah tatanan demokrasi dan struktur nilainilai dasarnya (Porath, 2007: 56)

Tetapi Ada ketegangan seperti yang diungkapkan Archard yang kurang menyenangkan terkait tuntutan bahwa patriotisme diajarkan dalam pengakuan dengan alasan kritis bagaimana menimbulkan korosif terhadap kondisi kemungkinan pengajaran itu. Pandangan ini bahwa baik untuk menjadi patriotik dan bermanfaat bagi warga negara yang mencintai negara mereka, adalah orang yang dapat dipertahankan dengan alasan kritis (Archard, 1999: 166). Maksud dari Archard disini yaitu mengkritisi pemerintah jangan ikut campur terlalu mendalam mengenai pengajaran patriotik kepada warga negara, karena akan berakibat tumbuhnnya patriotisme palsu dan memungkinkan terbentuknya nasionalis ekstrimis. Tekanan dari pemerintah dalam pengajaran sendiri tidak bisa memotivasi orang untuk menjadi patriot. Rasa keterikatan yang terlalu dipaksakan kepada warga negara akibat sikap superioritas pemerintah. Hal ini juga yang ditakutkan oleh Callan bahwa jika patriotisme diajarkan kepada siswa dengan alasan terbentuknya patriotik, justru patriot palsu yang akan tumbuh jika ditanamkan kepada siswa doktrin dan afiliasi poitik pemerintah sehingga siswa sebagai warga negara wajib dan tunduk kepada pemerintah tanpa sebuah pemikiran yang kritis (Callan, 2009: 523). Inilah yang menjadi perdebatan di dunia internasional terkait perlu atau tidaknya mengajarkan patriotisme didalam dunia pendidikan. Ini sebuah ketakutan yang berbuah menjadi sebuah perdebatan di dunia apakah ptriotisme jika diajarkan didunia pendidikan, terutama sekolah akan menanamkan patriotisme yang bersifat kiritis atau palsu. Karena tidak bisa dipungkiri 
peran atau ikut campur pemerintah dalam pembentukan kurikulum disekolah.

Di dalam buku Patriotism and Citizenship Education yang di edit Bruce Haynes, menjelaskan perkembangan pengajaran patriotisme baik itu di sekolah maupun di masyarakat oleh beberapa negara di dunia, seperti perkembangan pendidikan patriotisme di Inggris, peran pemerintah Amerika dalam penanaman patriotisme yang dituangkan dalam kurikulum di sekolah, dan sejarah perkembangan pendidikan patriotisme di Australia. Kita ambil contoh penerapan pendidikan patriotisme di Amerika. Amerika sendiri memulai penanaman patriotisme melalui pendidikan sekitar abad 18 dengan ditandai pemasangan bendera Amerika di ratusan sekolah dan rumah-rumah di Amerika, dengan tujuan pendidik di Amerika menggembleng sentimen nasionalisme kepada anak-anak di sekolah (Merry, 2009: 382). Karena pada saat itu terjadi perang saudara sehingga antusiasme untuk bersatu dalam mengembalikan identitas Amerika. Sekolah Negeri di Amerika menerbangkan bendera Amerika di halaman sekolah mereka, dan sebagian besar guru juga memiliki bendera atau gambar presiden di suatu tempat di kelas. Sebagian besar sekolah (terutama sekolah menengah atas) memiliki dewan pemerintah dan mahasiswa sekolah, yang dengan sengaja mencontoh kantor pemerintah tertentu di tingkat negara bagian dan federal. Sebagian besar sekolah menengah mengajarkan kelas kewrganegaraan, dimana perhatian diberikan pada fungsi pemerintah Amerika dan tugas dan tanggung jawab yang dimiliki oleh warganegara (Merry, 2009: 384). Jadi peran pemerintah Amerika sangat kuat dalam penanaman patriotisme di sekolah. Tetapi dalam perkembangannya guru-guru berusaha untuk bersikap independen independen dengan menanamkan patriotik kritis kepada siswa, dengan cara guru-guru di sekolah Amerika mempromosikan patriotisme melalui berbagai bentuk media, Pembaca Mingguan, surat kabar, majalah, televisi yang tak terhitung jumlahnya dan sumber Internet yang sering memberikan sudut pandang proAmerika (Merry, 2009: 384). Tentu saja, bagaimana seorang guru menggunakan media khususnya berbagai perspektif media dapat membantu melemahkan perspektif patriotik yang tidak kritis.

Di Inggris terjadi perdebatan apakah perlu mnegajarkan patriotisme atau tidak. Dalam hal ini Hand dan Perace melakukan sebuah penelitian di beberapa sekolah di Inggris dengan menyebarkan angket kepada siswa dan guru terkait urgensi pengajaran patriotisme di sekolah. Karen (2010: 144) dengan hasil analasisinya bahwa Pendidikan Kewarganegaraan di Inggris dalam kurikulumnya secara terstruktur mengupas nilai patriotik dengan menggunakan pendekatan kosmopolitan. Didukung dari hasil penelitiann bahwa 74 peresen guru setuju bahwa mereka memiliki kewajiban untuk mengajarkan kepada siswa terkait sentimen patriotisme di Inggris (Hand \& Pears, 2009: 460). Guru di Inggris berusaha bersikap netral dalam mengajarkan patriotisme kepada siswa, tidak ada intervensi atau ikut campur dari politik pemerintah Inggris Karena tujuan penanaman patriotik kritis kepada siswa supaya siswa berisikap independen, bebas dari organisasi, dan politik pemerintah (Michael Hand \& Joanne Pears, 2009: 460).

Sedangkan di Indonesia, apakah patriotisme diajarkan dalam ruang lingkup pendidikan di sekolah?. Di Indonesia, mata pelajaran patriotisme dalam disiplin pendidikan belum termuat dalam kurikulum nasional. Tetapi semangat patriotisme tertulis dalam konstitusi negara Indonesia yang tertulis jelas dalam pembukaan UUD 1945 alinea 1 dan 2 . Pendidikan patriotisme dalam penerapannya di Indonesia merupakan bagian dari ruang lingkup mata pelajaran Pendidikan Kewarganegaraan. Pendidikan Kewarganegaraan di Indonesia memiliki beberapa ruang lingkup sebagai kajian mata pelajaran di sekolah, diantaranya terdapat pada poin pertama, yaitu terciptanya persatuan dan kesatuan bangsa: meliputi hidup rukun dalam peradaban, cinta lingkungan, kebanggaan sebagai bangsa Indonesia, sumpah pemuda, keutuhan NKRI, partisipasi dalam bela negara, memiliki sikap positif terhadap NKRI, dan keterbukaan serta jaminan keadilan (UU No. 22 Th. 2006, standar isi: 108). Jadi Pendidikan 
Kewarganegaraan di Indonesia secara jelas dijadikan sebagai sebuah wahana untuk mengajarkan patriotisme untuk warga negara dengan maksud untuk menjaga keutuhan Negara Kesatuan Republik Indonesia. Bukan berarti mengajarkan patriotisme yang bersifat palsu, tapi lebih kepada true patriotism, selain menjaga keutuhan negara kesatuan republik Indonesia, siswa juga diajarkan toleransi dan saling menghargai dengan warga negara asing. Dengan penenaman patriotisme seperti ini diharapkan menjadi nasionalis dan patriotis sejati, bukan mengarah kepada nasionalis ekstrimis yang menganggap negaranya satusatunya yang paling benar dan kuat.

Dari beberapa contoh perlunya mengajarkan patriotisme di dibeberapa negara diatas, Michael Hand dan Joanne Pearce menyarankan empat pendekatan luas terhadap pengajaran patriotisme yang dapat dilakukan oleh sekolah. Pertama, sekolah bisa ikuti strategi penghindaran (politik pemerintah), menyekesaikan topik pelajaran kemudian diskusi ke wilayah yang lebih aman. Kedua, sekolah bisa mengadopsi sikap netral, mengundang diskusi patriotisme namun menyajikan secara terbuka terkait pertanyaan atau isu kontroversial. Ketiga, sekolah secara aktif mempromosikan perasaan patriotik, baik secara rasional, dengan menghadirkan siswa dengan alasan kuat untuk mencintai negara mereka.. Keempat, sekolah secara aktif mencegah patriotisme setia, sekali lagi dengan alasan rasional dengan menciptakan propaganda (Hand \& Pears, 2009: 454). Keempat saran pengajaran patriotisme ini dipayungi oleh Pendidikan Pendidikan Kewarganegaraan yang dalam menjamin integrasi warganegara dalam menghadapi pluralisme dan perpecahan diantara warga (Archard, 1999: 171). Oleh karena itu ajaran nasionalisme dan patriotisme harus diterima sebagai sebuah bagian dari kurikulum. Dengan memperluas gagasan patriotisme sebagaimana tercermin dalam bentuk proses pendidikanan guna memberikan kondisi untuk mewujudkan pemerintahan yang demokratis yang mengusung nilai-nilai toleransi sesama dan mengakui persamaan hak warga negara.

\section{Pendidikan Kewarganegaraan sebagai Bentuk Solutif dalam Membangun Nilai- Nilai Patriotisme}

Sebelum membicarakan konsep Pendidikan Kewarganegaraan, terlebih dahulu menjelaskan tentang konsep kewarganegaraan. Dalam hal ini T.H Marshal memberikan sumbangsih tentang konsep kewarganegaraan, yaitu kewarganegaraan adalah status yang diberikan pada orang-oarang yang memiliki anggota penuh dari sebuah komunitas dan semua orang statusnya setara dengan hak dan kewajibannya (Lister, 1997:14). Negara menjamin setiap hak-hak yang sama baik itu hak individu maupun hak konstitusional kepada warga negara dengan jaminan setiap warga negara memiliki kewajib an untuk taat kepada negaranya, salah satunya dengan menjaga stabilitas dan keutuhan negara. Sedangkan berbicara mengenai konsep Pendidikan Kewarganegaraan, maka akan mengacu dari teorinya Bronson. Menurut Branson (1999:4) Pendidikan Kewarganegaraan disebut juga Civic Education, memiliki pengertian yaitu pendidikan yang memiliki tujuan untuk mengembangkan serta memperkuat konsep sistem pemerintahan yang otonom. Maksud dari pemerintahan otonom disini yakni setiap warga negara ikut peran serta untuk pemerintahannya sendiri guna menciptakan sistem pemerintahan yang demokratis.

Pendidikan Kewarganegaraan dapat juga dikatakan sebagai sebuah program pendidikan yang mengkaji tentang konsep kebangsaan, Hak Asasi Manusia, demokrasi, masyarakat kewargaan (civil society) serta Pendidikan Kewarganegaraan dalam hubungannya dengan negara (Hamidi dan Lutfi, 2010: 78). Adapun tujuan pendidikan kewarganegaraan dapat dipahami baik itu dari skala sempit maupun luas. Dalam hal ini Pearce dan Hallgarten (2007: 7) mendefinisikan tujuan Pendidikan Kewarganegaraan dalam sekala sempit dan luas. Pendidikan Kewarganegaraan dalam arti sempit bertujuan untuk menghasilkan warga negara yang mampu 
menangani dalam hak pilih dan dari setiap pertarungan politik yang demokratis. Sedangkan dalam arti luas tujuannya yaitu untuk menciptakan warga yang berbagi dalam usaha sosial bersama. Maksud dari konsep sempit dari tujuan pendidikan kewarganegaraan disini yaitu pendidikan yang dirancang untuk menghasilkan warga negara yang terpelajar. Sehingga dalam learning outcome nya diharapkan siswa memiliki karakter jujur, benar, adil, terpercaya, serta memiliki kesadaran untuk mengabdi kepada negara (Clough and Holden, 2002: 2). Oleh karennya mengajarkan Pendidikan Kewarganegaraan dalam lingkup sekolah sangat diperlukan untuk membentuk warganegara yang mengenal jati diri dan negaranya. Sedangan tujuan secara luas dari Pendidikan Kewarganegaraan yaitu untuk menghasilkan warga negara yang aktif dengan komitmen terhadap nilai dan praktik kepada masyarakat. Pendidikan Kewarganegaraan mengenai pandangan ini tidak hanya mencakup melek politik tetapi juga diaharapkan tercipta masayarakat yang bermoral dan bertanggung jawab sosial dalam keterlibatan di dunia sosial (Halstead and Pike, 2006: 34).

Pendidikan Kewarganegaraan pada dasarnya mengajarkan tentang kesetiaan dan rasa cinta akan tanah air yang biasa disebut dengan patriotisme. Patriotisme sejati akan mengajarkan bagaimana warga negara yang memiliki kesetiaan dan loyalitas terhadap negara serta menegenali identitas yang dimiliki oleh negara masing-masing. Hal ini didukung drai hasil tesis Mc Donough (2013: 135-150) menyatakan gerakan nasionalis dan patriotik berperan kuat memperkokoh pilar-pilar prinsip Pendidikan Kewarganegaraan nilai-nilai demokratis.

Pendidikan Kewarganegaraan memiliki peran yang sangat penting mengenai pemahaman negara serta memberikan pengetahuan tentang bagaimana menjadi warganegara yang mencintai tanah air. Sehingga Eamon Callan dan William Galston keduanya melihat bahwa pentingnya Pendidikan Kewarganegaraan dalam menyatukan warga negara terhadap kesetiaan patriotik untuk mencapai sebuah konsensus yaitu satu identitas nasional (Archard, 1999: 158),. Jadi Callan dan Galston menuntut tujuan dari Pendidikan Kewarganegaraan bersifat konsisten dengan alasan yang kritis dan mengandung nilai-nilai pemersatu untuk menciptakan warganegara yang patriotik. Rasa kewarganegaraan bersama dapat memberi alasan dimana warga negara tertentu dimotivasi untuk menerima, dan hidup dengan seperangkat prinsip keadilan. Dalam sebuah bangsa yang ideal, telah dikemukakan lebih jauh lagi, bahwa keberhasilan demokrasi deliberatif memerlukan kepercayaan di antara mereka yang berunding dan berkeinginan untuk menemukan kesepakatan kerjasama sosial yang disepakati (Archard, 1999: 160). Jadi mengajarkan Pendidikan Kewarganegaraan merupakan dasar pendidikan yang tepat untuk menanamkan citacita yang tidak menghianati patriotisme sebagaimana yang dikatakan Miller bahwa kewarganegaraan seoranga bagian yang terpenting dari identitasnya.

\section{SIMPULAN}

Eamonn Callan dan William Galston memberikam sebuah solusi bahwa Pendidikan Kewarganegaraan memiliki peran penting dalam melawan tatanan pluralisme destruktif dengan tujuan untuk menyatukan warga negara melalui sebuah kesetiaan patriotik yang dijadikan sebagai identitas nasional. Karena pendidikan kewarganegaraan menjadi alat sosialisasi dalam membentuk warga negara yang sadar akan hak dan kewajibannya dalam bela negara dengan tidak menafikan kedaulatan negara lain. Walaupun terdapat beberapa kritikus anti patriot mengungkapkan ketidaksetujuan dalam mengajarkan patriotisem karena berkaca dari sejarah perang dunia pertama dan kedua diamana nama patriotisme seolah-olah tercoreng karena tersisip kepentingan politik distruktif yang memyebabkan warga negara terseret dalam sebuah kesetiaaan yang palsu. Archard menekankan pada perlunya mennanmkan nilai-nilai patriotisme kritis yang merupakan tuntutan utama karena tujuannya yaitu supaya 
warga negara merasa memiliki identitas dan mencintai negara mereka serta menjadi suatu alasan yang dapat dipertahankan secara kritis melalui Pendidikan Kewarganegaraan.

\section{DAFTAR PUSTAKA}

Archard, D. (1999). Should We Teach Partriotism?. Studies In Philosophy and Education, 1 (18), 157-173.

Bronson, M. (1999). Belajar Civic Education dari Amerika. Yogyakarta: The Asia Foundation.

Callan, M. (2009). The Better Angels of Our Nature: Patriotism and Dirty Hand. the journal of political philosophy, 18 (3), 249270.

Clough, N \& Holden, C. (2002). Education for Citizenship: Ideas into Action. London: Routledge Taylor \& Prancis Group.

Encep, S.N. (2017). Cicic Education Policies: Their Effect on University Student Spirit of Nationalism and Patriotism. Citizenship social \& economics education. 16 (1), 69-82

Hand, M. \& Pearce, J. (2009). Patriotism in British Schools: Priciples, Practices and Press Hysteria. Journal Educational Philosopy and Theory. 41 (4), 453-465.

Halstead, M.J, et.al. (2006). Citizenship and Moral Education: Values and Action. New York: Routledge Taylor \& Prancis Group

Hamidi, J. \& Lutfi, M. (2010). Civic Education Antara Realitas Politik dan Implementasi Hukumnya. Jakarta. Gramedia Pustaka Utama.

Haynes, B. (2009). Patriotism and Citizenship Education. United Kingdom: Philosophy of Edudation Society Theory.

Herbert, A.G,. (2012). Patriotism and Nationalism in Music Education. United Kingdom: MGP Books Group.

Karen, R. (2010). Patriotism and Citizenship Education. Citizenship social and economical education. 9 (2), 144-145

Kartodirdjo, S. (1992). Pengantar Sejarah Indonesia Baru, Sejarah Pergerakan Nasional dan Kolonialisme Sampai Nasionalisme. Jakarta: Gramedia.

Kateb, G. (2006). Patriotism and Other Mistakes. New Haven, CT: YaleUniversity Press

Kanako, I. (2009). The Debate on Patriotic Education in Post-World War II Japan. Journal Education Philosophy and Theory. 41 (4), 441-452.

Lister, R. (1997). Citizenship: Feminist Perspectives. New York: University Press.

Merry, M.S. (2009). Patriotism, History and The Legitimate Aim of American Education. Journal Educational Philosopy and Theory. 41 (4), 378-398.

Macedo, S. (2011). Jus Patriot?. Philosophy and social critism. 37 (4), 413-423.

Donough, K.M. (2013). Beyond Patriotic Education: Locating the Place of Nationalism in the Public School Curriculum. Education, chitizenship and social justice. 8 (2), 135-150.

Novitasari. I.R. (2013). Penanaman Nilai Nasionalisme dan Patriotisme untuk Mewujudkan Pendidikan Karakter pada Mata Pelajaran PKn Siswa Kelas X Negeri 4 Siduarjo. Jurrnal IPI, Kajian Moral dan Kewarganegaraan. 1 (1), 39-54.

Palumbo, A. (2009). Patriotism and Pluralism: Identification and Compliance in the PosNational Polity. Journal Ethics \& Global Politics. 2 (4), 321-3.

Patrick (1999) "Concepts at The Core of Education and Democratic Citizenship" dalam Bahmueller, C \& Patrick, J (eds). (1999). Principles and Practicies of Education for Democratic Citiznship. Indiana: ERIC

Pemerintah RI. (2006). Permendiknas No. 22 Tahun 2006 tentang Standar Isi untuk Satuan Pendidikan Dasar dan Menengah.

Porath, S.B. (2007). Civic Virtue of Necessity: Patriotism and Democratic Education. Jurnal Theory and Research Education. 5 (1), 41-59

Pearce,N \& Hallgarten, J. (2000). "Introduction" Tommorow Citizens: Critical Debates in Citizenship and Education. London: Instute for Public Policy Reaseach. 
Smith, A.D. (1991). National Identity. England: Penguin Book

Zembylas, M. (2013). The Teaching of Patriotism and Human Rights: An unease entanglement and the contribution of critical pedagogi. Journal Education Philosophy Theory. 46 (10), 11143-1159. 